\title{
MENGATASI FIBRILASI ATRIUM RAPID RESPONSE DENGAN BISOPROLOL
}

\author{
Franky A. Tumiwa \\ Reginald L. Lefrandt
}

\author{
Divisi Kardiologi Bagian Ilmu Penyakit Dalam \\ Fakultas Kedokteran Universitas Sam Ratulangi Manado \\ Email: anq23wa@yahoo.com
}

\begin{abstract}
We reported a 77-year old female, admitted to the Prof dr RD Kandou General Hospital due to dyspnea. Physical examination revealed hypertension, rales and wheezing in both lungs, heart enlargement, and an auscultation heart rate of 140 beats per minute. ECG showed a rapid response atrial fibrillation. Besides that, chest $\mathrm{X}$ ray examination showed cardiomegaly with CTR $>50 \%$. A working diagnosis revealed lung edema (pneumonia as a differential diagnosis), and functional heart failure class II-III due to hypertensive heart disease, associated with a rapid response atrial fibrillation. Bisoprolol $5 \mathrm{mg}$ once daily was given immediately along with oxygen, a NaCL $0.9 \%$ infusion, and furosemide $40 \mathrm{mg}$ intravenously. In addition to this, was added ceftriaxon $1 \mathrm{~g}$ twice daily, captopril $6.25 \mathrm{mg}$ three times daily, furosemide $40 \mathrm{mg}$, thiazide $25 \mathrm{mg}$, and aspirin $80 \mathrm{mg}$ once daily, coenzyme Q10 $100 \mathrm{mg}$ twice daily, and trimetazidine $35 \mathrm{mg}$ two tablets daily. The ECG result after approximately 10 hours was a normal respone atrial fibrillation. The patient left the hospital at the fifth day with the same ECG result.
\end{abstract}

Keywords: atrial fibrillation, bisoprolol, congestive heart failure

\begin{abstract}
Abstrak: Telah dilaporkan seorang perempuan berusia 77 tahun, dirawat di RSU Prof dr RD Kandou dengan keluhan sesak napas. Pada pemeriksaan fisik ditemukan hipertensi, adanya ronki dan wheezing, pada perkusi pembesaran jantung, auskultasi frekuensi denyut jantung 140 kali per menit. EKG memperlihatkan fibrilasi atrium rapid response. Selain itu pada foto dada tampak kardiomegali dengan CTR $>50 \%$. Diagnosis kerja adalah suspek pneumonia, gagal jantung kongestif fungsional kelas I-III karena penyakit jantung hipertensi, disertai fibrilasi atrium rapid response. Pemberian bisoprolol $5 \mathrm{mg}$ sekali sehari telah dimulai sejak saat masuk, disertai pemberian oksigen, infus cairan Nacl 0,9\%, dan furosemid $40 \mathrm{mg}$ intra venous. Kemudian ditambahkan ceftriaxon $1 \mathrm{~g}$ dua kali sehari, captopril 6,25 mg tiga kali sehari, tiazid $25 \mathrm{mg}$ sekali sehari, furosemid $40 \mathrm{mg}$ sekali sehari, coenzim Q10 $100 \mathrm{mg}$ dua kali sehari, trimetazidine $35 \mathrm{mg}$ dua tablet sehari, dan aspirin $80 \mathrm{mg}$ sekali per hari. Pada hari kedua EKG telah memperlihatkan gambaran fibrilasi atrium normal response. Pasien dipulangkan pada hari ke lima dengan diagnosis gagal jantung kongestif fungsional I-II karena penyakit jantung hipertensi, hipertensi terkontrol, dan fibrilasi atrium normal response.
\end{abstract}

Kata kunci: fibrilasi atrium, bisoprolol, gagal jantung kongestif

Fibrilasi atrium adalah salah satu kelainan pada irama jantung yang bersifat ireguler atau aritmia sebagai akibat adanya impulsimpuls abnormal pada jantung. Kelainan ini dapat berlangsung terus menerus atau hilang timbul. Fibrilasi atrium merupakan penye- bab tersering dari suatu takiaritmia. ${ }^{1}$

Insidensi penyakit ini meningkat seiring dengan peningkatan usia. Fibrilasi atrium sering dijumpai pada usia lanjut, terutama mereka yang juga menderita penyakitpenyakit kardiovaskuler seperti hipertensi, 
hipertrofi ventrikel kiri dan gagal jantung. Gejala-gejala fibrilasi atrium sering tidak tampak, namun jika tidak ditangani dengan baik maka fibrilasi atrium dapat menyebabkan terjadinya stroke, memburuknya fungsi otot jantung, bahkan kematian. ${ }^{1,2}$

Pemberian terapi farmakologis dalam menangani fibrilasi atrium terutama untuk mengembalikan serta mempertahankan keadaan irama sinus, kontrol terhadap irama ventrikel, dan pencegahan terhadap stroke serta komplikasi-komplikasi lainnya, dengan harapan terjadi perbaikan kualitas hidup pasien. $^{2}$

Hal penting yang harus diperhatikan dalam mengobati suatu fibrilasi atrium adalah faktor keamanan obat yaitu efek langsung terhadap jantung, efek di luar jantung (efek ekstrakardiak), serta kontraindikasi obat-obat antiaritmia selektif. Farmakoterapi pada pasien dengan fibrilasi atrium ditujukan pada kontrol terhadap irama (rhythm control) atau kontrol terhadap laju (rate control). ${ }^{3}$

Berikut ini akan dilaporkan sebuah kasus dengan fibrilasi atrium yang dirawat di unit rawat jantung intensif RSU. Prof. dr. R.D. Kandou Manado.

\section{LAPORAN KASUS}

Seorang perempuan berusia 77 tahun, suku Gorontalo dirawat di RSU Prof. dr. R.D. Kandou Manado sejak tanggal 11 Januari 2009 jam 20.00 wita, dengan keluhan utama sesak napas. Sesak napas dialaminya sejak empat hari sebelum masuk rumah sakit, yang menghebat pada beberapa jam sebelum masuk rumah sakit. Sesak napas bertambah hebat bila ia beraktifitas dan berkurang bila beristirahat. Kadang-kadang ia mengeluhkan adanya serangan sesak malam hari. Batuk dialaminya sejak satu bulan lalu dengan lendir berwarna putih, tidak bercampur darah. Keringat pada malam hari tidak dikeluhkan. Penurunan nafsu makan dirasakannya kira-kira satu minggu sebelum masuk rumah sakit. Nyeri ulu hati, mual dan muntah, serta panas tidak dikeluhkan olehnya. Buang air besar dan buang air kecil seperti biasa. Riwayat penyakit dahulu adalah hipertensi yang diketahui sejak lima tahun yang lalu, tetapi ia tidak minum obat secara teratur. Riwayat penyakit gula, ginjal, stroke, jantung dan paru-paru disangkal olehnya. Demikian pula riwayat kebiasaan konsumsi alkohol dan merokok.

Pada pemeriksaan fisik ditemukan keadaan umum tampak sakit berat kesadaran kompos mentis, tekanan darah 160/90 $\mathrm{mmHg}$, nadi 98 kali per menit ireguler, pernapasan 48 kali per menit dan suhu badan $36,6^{\circ} \mathrm{C}$. Konjungtiva tidak anemis, sklera tidak ikterik, pupil bulat isokor, refleks cahaya positif normal, tidak tampak kelainan pada telinga, hidung dan tenggorokan, serta bibir tidak tampak sianosis. Tekanan vena jugularis $5+2 \mathrm{~cm}$, trakea letak ditengah, tidak tampak pembesaran kelenjar getah bening dan kelenjar tiroid. Pada pemeriksaan dada bagian depan dan belakang, dari hasil inspeksi tidak ditemukan kelainan. Pemeriksaan paru bagian depan, inspeksi gerakan pernapasan simetris dalam keadaan statis dan dinamis, palpasi fremitus raba pada paru kiri sama dengan kanan, perkusi sonor pada kedua paru, batas paru hati pada linea midklavikularis kanan sela iga ke VI dengan peranjakan $1 \mathrm{~cm}$. Suara pernapasan bronkovesikuler di kedua paru dan ditemukan adanya ronki dan wheezing pada kedua lapangan paru. Pemeriksaan paru bagian belakang, inspeksi gerakan pernapasan simetris dalam keadaan statis dan dinamis, palpasi fremitus raba kiri sama dengan kanan, perkusi sonor, dan pada auskultasi suara pernapasan vesikuler serta ditemukan adanya ronki dan wheezing pada kedua lapangan paru. Pemeriksaan jantung, inspeksi iktus kordis tampak, palpasi iktus kordis teraba di sela iga $\mathrm{V}$ pada $1 \mathrm{~cm}$ lateral garis midklavivula kiri dan kuat angkat. Pada perkusi ditemukan batas kiri jantung berada pada $1 \mathrm{~cm}$ lateral sela iga $\mathrm{V}$ garis midklavikula kiri, batas kanan jantung sela iga IV garis parasternalis kanan. Auskultasi frekuensi denyut jantung 140 kali per menit, ireguler, dan tidak terdengar adanya bising. Pada pemeriksaan abdomen tampak datar, lemas, hati dan limpa tidak teraba, bising usus normal dan ginjal tidak teraba. Pada pemeriksaan anggota gerak akral hangat, tidak sianosis dan tidak 
terdapat edema.

Pemeriksaan laboratorium tanggal 11 Januari 2009 ditemukan hemoglobin 12,9 gr\%, hematokrit $38,9 \%$, lekosit $8.100 / \mathrm{mm}^{3}$ dan trombosit $338.000 / \mathrm{mm}^{3}$. Pada pemeriksaan elektrolit didapatkan natrium 138 $\mathrm{mEq} / \mathrm{L}$, kalium 3,9 mEq/L dan klorida 104 $\mathrm{mEq} / \mathrm{L}$. Pada pemeriksaan elektrokardiografi (EKG) pada jam 20.30 wita didapatkan gambaran fibrilasi atrium rapid response dengan frekuensi 214 kali per menit (Gambar 1). Berdasarkan anamnesis, pemeriksaan fisik dan pemeriksaan penunjang, maka pasien ini didiagnosis kerja sebagai suspek edema paru akut dengan diagnosis banding pneumonia, dan fibrilasi atrium rapid response. Pada pasien ini diberikan terapi dengan oksigen 4-6 liter/menit, infus $\mathrm{NaCl}$ $0,9 \% 7$ tetes per menit, furosemid $40 \mathrm{mg}$ iv, dan bisoprolol $5 \mathrm{mg}$ per hari. Pada jam 23.00 wita pasien dipindahkan ke ruang perawatan jantung intensif. Keadaan umum tampak sakit sedang kesadaran kompos mentis, tekanan darah $110 / 70 \mathrm{mmHg}$, nadi 88 kali per menit ireguler, pernapasan 28 kali per menit, suhu badan $36,6^{\circ} \mathrm{C}$. Dilakukan pemeriksaan EKG dan didapatkan gambaran fibrilasi atrium rapid response frekuensi 167 kali per menit (Gambar 2).

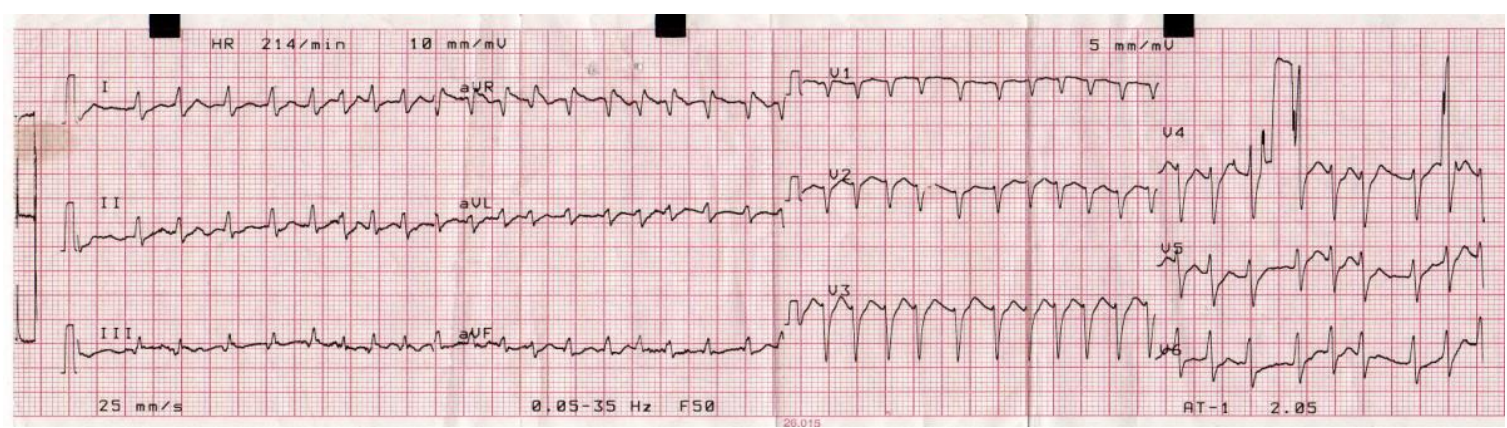

Gambar 1. EKG tgl 11 Januari 2009 jam 20.30 memperlihatkan gambaran fibrilasi atrium (rapid response) dengan frekuensi 214 kali per menit.
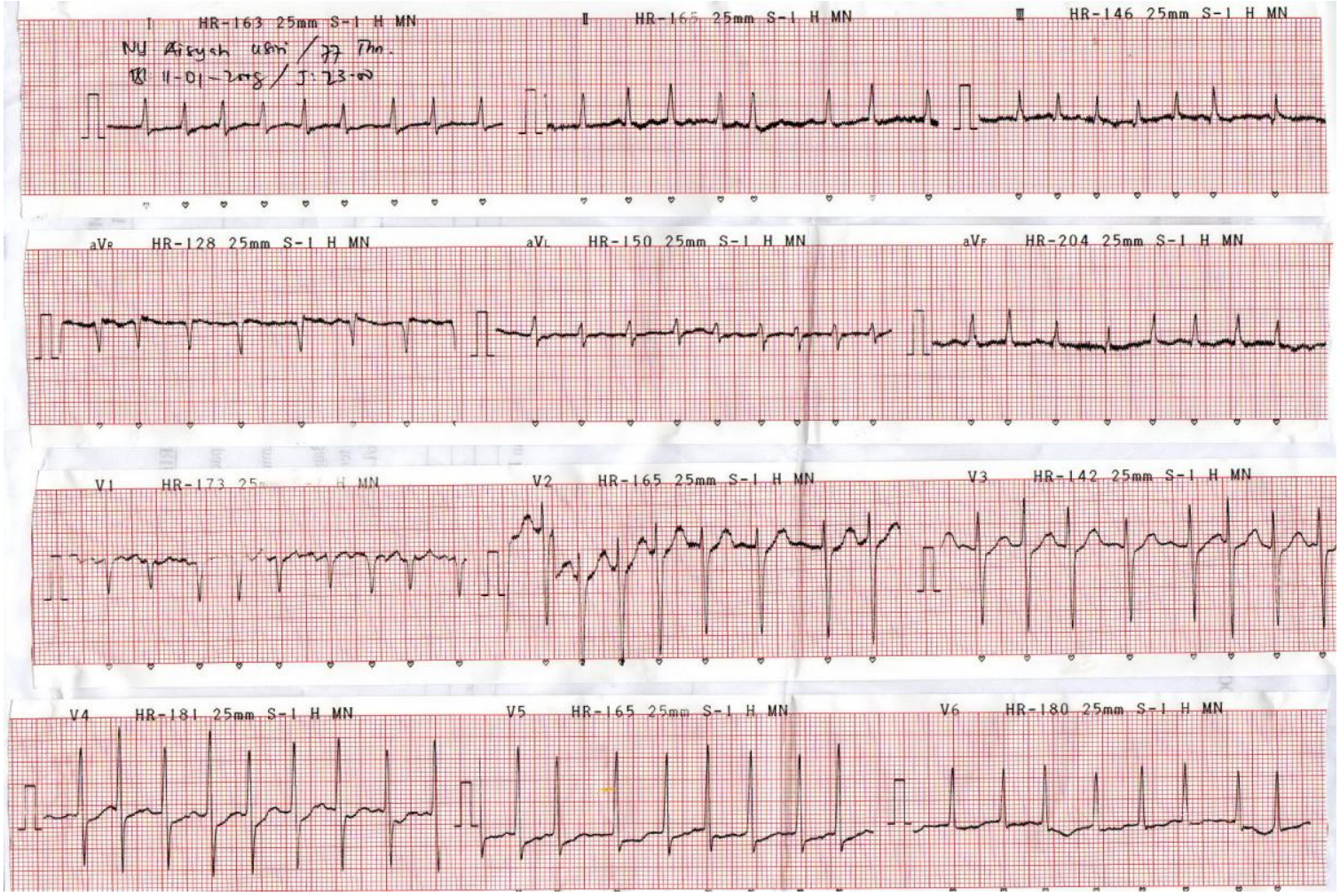

Gambar 2. EKG tgl 11 Januari 2009 jam 23.00 memperlihatkan gambaran fibrilasi atrium (rapid response) frekuensi 167 kali per menit 
Pasien didiagnosis dengan suspek pneumonia, gagal jantung kongestif fungsional II-III karena penyakit jantung hipertensi, dengan fibrilasi atrium rapid response. Terapi yang diberikan adalah oksigen 3-4 liter/menit, infus cairan $\mathrm{NaCl}$ $0,9 \% 7$ tetes per menit, ceftriaxon $1 \mathrm{gr}$ dua kali sehari, captopril $6,25 \mathrm{mg}$ tiga kali sehari, bisoprolol $5 \mathrm{mg}$ sekali sehari, tiazid $25 \mathrm{mg}$ sekali sehari, aspirin $80 \mathrm{mg}$ sekali sehari, coenzim Q10 $100 \mathrm{mg}$ dua kali sehari, dan trimetazidine $35 \mathrm{mg}$ dua tablet sehari.

Pada hari kedua perawatan tanggal 12 Januari 2009, dilakukan pemeriksaan EKG dan didapatkan gambaran fibrilasi atrium normal response (Gambar 3). Keluhan sesak sudah berkurang. Keadaan umum pasien tampak sakit sedang, tekanan darah 120/80 mmHg, nadi 84 kali per menit, ireguler, isi dan tegangan cukup, pernapasan 28 kali per menit, suhu badan $36,5^{\circ} \mathrm{C}$. Terapi yang diberikan adalah oksigen 2-3 liter/menit, infus cairan $\mathrm{NaCl} 0,9 \% 7$ tetes per menit, ceftriaxon $1 \mathrm{~g}$ dua kali sehari, captopril 6,25 mg tiga kali sehari, bisoprolol $5 \mathrm{mg}$ sekali sehari, tiazid $25 \mathrm{mg}$ sekali sehari, furosemide $40 \mathrm{mg}$ sekali sehari, coenzim Q10 $100 \mathrm{mg}$ dua kali sehari, trimetazidine $35 \mathrm{mg}$ dua tablet sehari, dan aspirin $80 \mathrm{mg}$ sekali per hari.

Pada hari ketiga perawatan tanggal 13 Januari 2009 didapatkan hasil pemeriksaan laboratorium gula darah sesaat $85 \mathrm{mg} / \mathrm{dl}$, kolesterol total $138 \mathrm{mg} / \mathrm{dl}$, trigliserida 108 $\mathrm{mg} / \mathrm{dl}$, ureum $52 \mathrm{mg} / \mathrm{dl}$, kreatinin 1,2 mg/dl, asam urat $5,1 \mathrm{mg} / \mathrm{dl}$, SGOT $56 \mathrm{u} / \mathrm{l}$, dan SGPT $44 \mathrm{u} / \mathrm{L}$. Keluhan sesak sudah jauh berkurang. Keadaan umum pasien tampak sakit sedang, tekanan darah 110/60 $\mathrm{mmHg}$, nadi 80 kali per menit, ireguler, isi dan tegangan cukup, pernapasan 24 kali per menit, suhu badan $36,6^{\circ} \mathrm{C}$. Produksi urine $1500 \mathrm{cc} / 24$ jam. Dari hasil pemeriksaan foto dada didapatkan gambaran kardiomegali dengan cardiothoracic ratio $(\mathrm{CTR})>50 \%$ (Gambar 4).

Pasien didiagnosis dengan gagal jan-

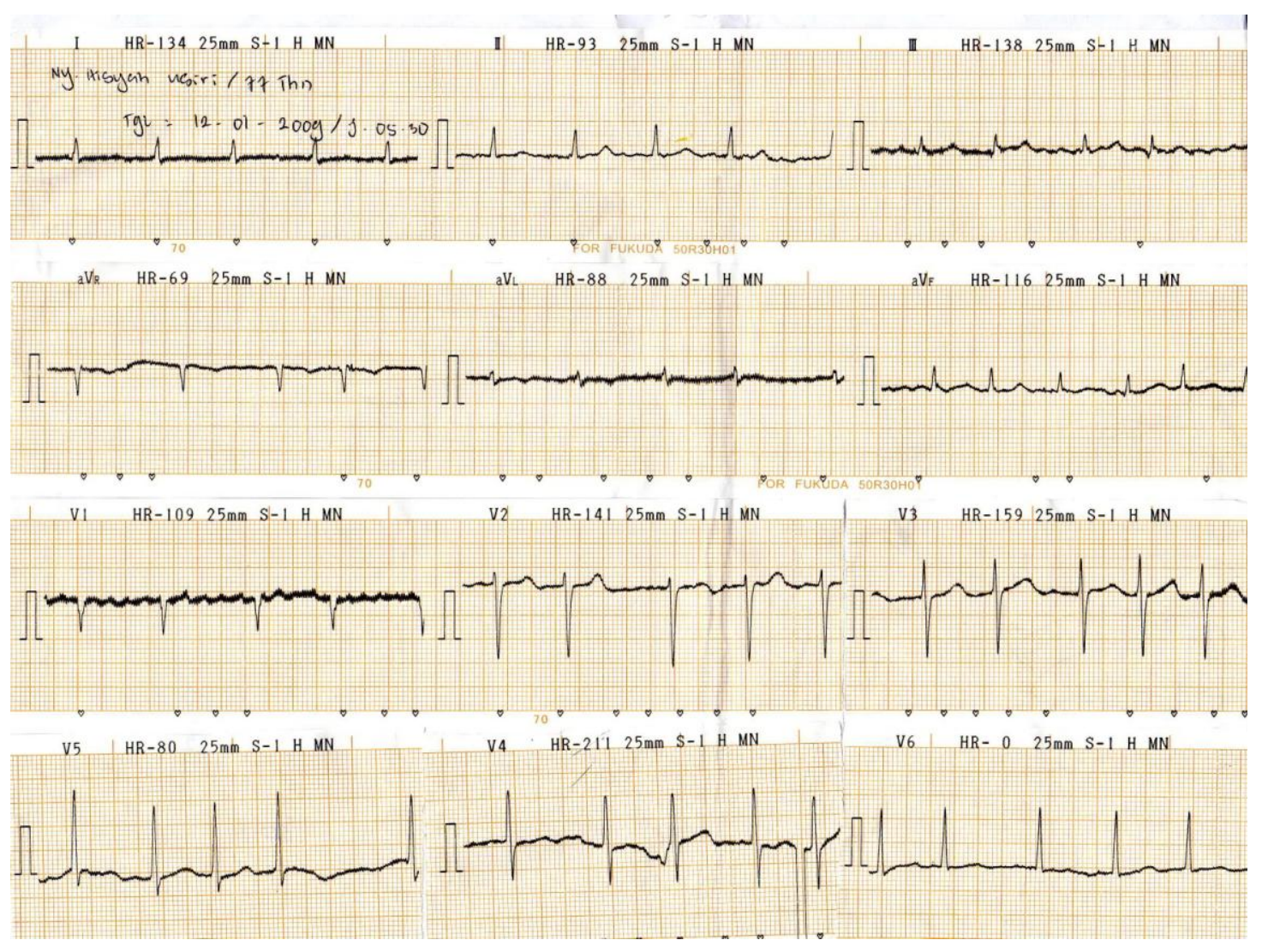

Gambar 3. EKG tanggal 12 Januari 2009 Jam 05.30 memperlihatkan gambaran fibrilasi atrium (normal response). 


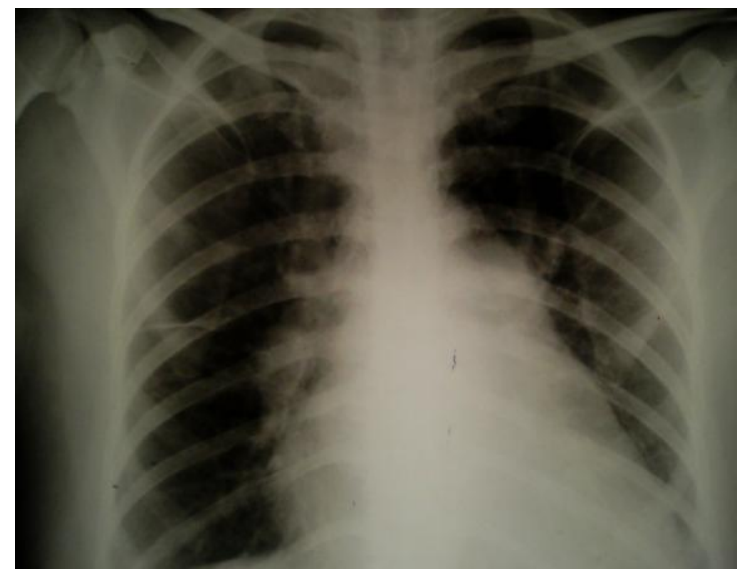

Gambar 4. X-foto dada pasien yang memperlihatkan gambaran kardiomegali dengan CTR $>50 \%$

tung kongestif fungsional II-III karena penyakit jantung hipertensi, dengan fibrilasi atrium normal response. Terapi yang diberikan captopril 6,25 mg tiga kali sehari, bisoprolol $5 \mathrm{mg}$ sekali sehari, tiazid $25 \mathrm{mg}$ sekali sehari, coenzim Q10 100 mg dua kali sehari, trimetazidine $35 \mathrm{mg}$ dua tablet sehari, dan aspirin $80 \mathrm{mg}$ sekali sehari.

Pada hari ke lima perawatan tanggal 15 Januari 2009 keadaan umum pasien tampak sakit sedang, tekanan darah 110/70 $\mathrm{mmHg}$, nadi 84 kali per menit, ireguler isi dan tegangan cukup, pernapasan 22 kali per menit, suhu badan $36,3^{\circ} \mathrm{C}$. Pada pemeriksaan EKG didapatkan gambaran fibrilasi atrium normal response (Gambar 5). Pada pemeriksaan laboratorium didapatkan hasil Free T4 (FT4) 0,875 mcg/dl dan Thyroid stimulating hormones (TSHs) 2,232 mU/mL. Pasien didiagnosis dengan gagal jantung kongestif fungsional I-II karena penyakit jantung hipertensi dengan fibrilasi atrium normal response. Pasien dipulangkan dan dianjurkan untuk kontrol di poliklinik jan- tung RSU Prof. dr. R.D. Kandou. Terapi yang diberikan saat pulang adalah captopril $6,25 \mathrm{mg}$ tiga kali sehari, bisoprolol $5 \mathrm{mg}$ sekali sehari, tiazid $25 \mathrm{mg}$ sekali sehari, coenzim Q10 100 mg dua kali sehari, trimetazidine $35 \mathrm{mg}$ dua tablet sehari, dan aspirin $80 \mathrm{mg}$ sekali sehari.

Pada tanggal 21 Januari 2009 pasien datang kontrol di poliklinik jantung RSU Prof. dr. R.D. Kandou. Keluhan sesak napas saat itu sudah jauh berkurang, batuk dan nyeri dada tidak dikeluhkan. Tekanan darah 130/70 mmHg, nadi 72 kali per menit, bersifat ireguler, isi dan tegangan cukup. Pasien didiagnosis dengan gagal jantung kongestif fungsional I-II karena penyakit jantung hipertensi, hipertensi terkontrol, dan fibrilasi atrium normal response. Terapi yang diberikan adalah captopril 12,5 mg tiga kali sehari, bisoprolol $5 \mathrm{mg}$ sekali sehari, tiazid $12,5 \mathrm{mg}$ sekali sehari, dan aspirin $80 \mathrm{mg}$ sekali sehari.

\section{PEMBAHASAN}

Fibrilasi atrium adalah kelainan pada irama jantung yang dicirikan oleh adanya gelombang ireguler dan bervariasi dalam ukuran, bentuk, serta jaraknya dalam suatu pemeriksaan EKG sebagai akibat adanya impuls-impuls listrik abnormal pada jantung. ${ }^{1-3}$

Pada fibrilasi atrium, terjadi impuls multipel yang menjalar ke dinding atrium pada waktu bersamaan, menyebabkan kontraksi atrium yang tidak terorganisir, kacau, dan sangat cepat. Pada keadaan ini atrium dapat berkontraksi sebanyak 400-600 kali per menit. Impuls-impuls ireguler ini mencapai nodus atrioventrikularis (nodus

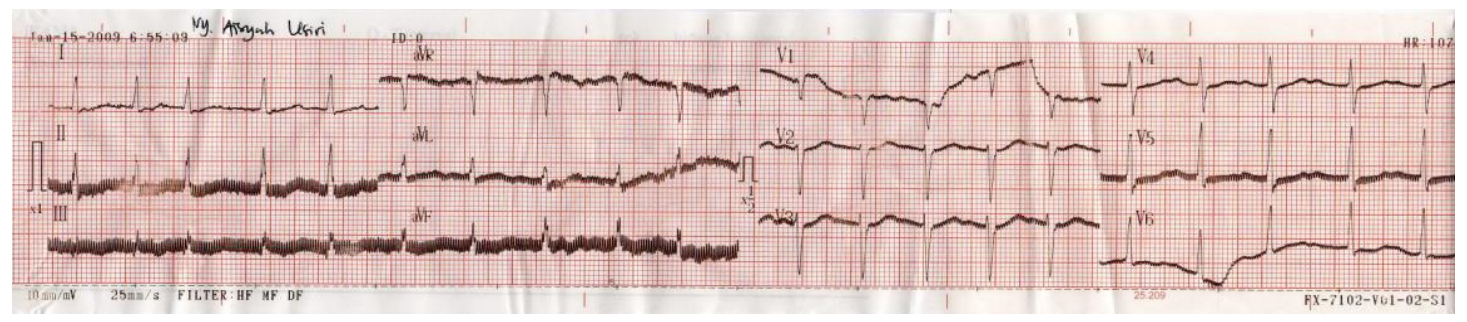

Gambar 5. EKG tanggal 15 Januari 2009 Jam 08.00 memperlihatkan gambaran fibrilasi atrium (normal response). 
AV) dengan cepat, namun tidak semuanya akan diteruskan, sehingga kontraksi ventrikel akan lebih lambat dari kontraksi atrium, biasanya 110-180 kali per menit dengan irama yang ireguler. ${ }^{3}$

Fibrilasi atrium berhubungan erat dengan faktor-faktor risiko kardiovaskuler dan usia. Hipertensi, diabetes, dan penyakit arteri koroner dapat mempermudah terjadinya fibrilasi atrium. Penyebab utama dari fibrilasi atrium yaitu adanya gangguan hemodinamik dimana peningkatan tekanan intraatrial menyebabkan perubahan dalam struktur atrium dan sistem listrik sehingga menjadi faktor predisposisi terjadinya fibrilasi atrium. Penyakit katup mitral dan trikuspid, disfungsi ventrikel kiri, dan gagal jantung kongestif adalah penyebab utama terjadinya peningkatan intra-atrial. Hipertensi sistemik atau pulmoner juga merupakan faktor predisposisi terjadinya kelebihan tekanan intraatrial. ${ }^{1}$ Penyakit arteri koroner secara langsung dapat menyebabkan keadaan iskemik dari atrium serta mencetuskan fibrilasi atrium. ${ }^{2}$ Juga perlu diperhatikan bila terdapat miokarditis dan perikarditis yang idiopatik atau terjadi bersama-sama dengan penyakitpenyakit kolagen, infeksi virus atau bakteri, serta pembedahan jantung, esofagus atau pembedahan toraks. ${ }^{3}$ Obat-obat stimulan, alkohol, dan kokain dapat memicu terjadinya fibrilasi atrium. Hipertiroidisme dan phaeochromocytoma juga dapat menyebabkan fibrilasi atrium. Proses intrakranial seperti perdarahan subaraknoid atau stroke dapat mencetuskan fibrilasi atrium. Brugada dkk melaporkan adanya defek pada kromosom 6q14-16 dan 11p15 dengan gen KCNQ1 yang dapat mengkode beberapa tipe dari saluran kalium yang terdapat pada otot jantung. ${ }^{3}$ Pada pasien ini faktor risiko terjadinya fibrilasi atrium adalah hipertensi, usia, dan gagal jantung kongestif.

Studi epidemiologis yang bersifat longitudinal dari The Framingham Heart Study yang dimulai sejak tahun 1948 melaporkan bahwa pada akhir penelitan selama 38 tahun dari 4731 subyek ternyata sebanyak 562 yang mendapat serangan fibrilasi atrium, dengan usia berkisar 55 hingga 94 tahun, tanpa riwayat fibrilasi atrium sebelumnya.,
Kasus ini adalah seorang perempuan berusia 77 tahun.

Gejala klinik dari fibrilasi atrium bervariasi pada setiap orang. Pada sebagian kasus tidak mengeluhkan adanya gejala apapun, sedangkan yang lainnya mengeluhkan dada berdebar, kepala terasa ringan atau bahkan pingsan, kelemahan umum, sesak napas, serta adanya nyeri dada. ${ }^{1-3}$ Pada pasien ini gejala yang muncul adalah sesak napas.

Pemeriksaan EKG dapat dipakai untuk menegakkan diagnosis suatu fibrilasi atrium. Pada pemeriksaan EKG didapatkan kontraksi atrium (gelombang P) yang lebih dari 400 kali per menit, serta irama jantung ireguler (interval R-R) yang berbeda-beda. Pada pasien ini didapatkan gambaran fibrilasi atrium yang dicirikan oleh adanya gelombang $\mathrm{P}$ multipel dengan interval $\mathrm{R}-\mathrm{R}$ yang bersifat ireguler. ${ }^{1-3,6}$

Pemeriksaan darah lengkap, fungsi tiroid, hati, dan ginjal dilakukan terutama dalam mencari faktor-faktor predisposisi terjadinya fibrilasi atrium. ${ }^{6}$ Pada pemeriksaan darah lengkap, fungsi tiroid, hati, dan ginjal pasien ini didapatkan hasil yang normal.

Pemeriksaan pencitraan jantung dibutuhkan untuk mencari penyebab dari fibrilasi atrium. Pemeriksaan-pemeriksaan ini meliputi transthoracic echocardiogram (TTE), transesophageal echocardiogram (TEE), computed tomography (CT) atau magnetic resonance imaging (MRI) dan chest radiography. Pada pasien ini hanya dilakukan pemeriksaan chest radiography, dimana didapatkan gambaran kardiomegali dengan CTR > 50\% sedangkan parenkim paru masih dalam batas normal.

Tujuan pengobatan suatu fibrilasi atrium adalah menurunkan risiko terjadinya tromboembolisme serta mengontrol keluhan/gejala yang ditimbulkan. Hal ini dapat dicapai dengan mengendalikan frekuensi ventrikuler selama berlangsungnya fibrilasi atrium, dan/atau mempertahankan irama sinus normal. Terapi farmakologis fibrilasi atrium adalah dengan pemberian antikoagulan, kontrol terhadap frekuensi (rate control), dan kontrol terhadap irama (rhythm 
control). Pemberian terapi antikoagulan ditujukan untuk menurunkan risiko terjadinya stroke, terutama pada pasien berusia $>60$ tahun, adanya riwayat tromboembolisme, diabetes melitus, penyakit arteri koroner, hipertensi, gagal jantung, dan tirotoksikosis. $^{8-10}$

Nilai international normalized ratio (INR), yang direkomendasikan adalah 2,0 sampai 3,0. Risiko terjadinya stroke meningkat 2 kali ketika INR berada dibawah 1,7 akan tetapi risiko terjadinya perdarahan, juga strok hemoragik meningkat jika INR lebih dari 3,5. Pada beberapa pasien dengan risiko yang relatif rendah, tidak membutuh- kan pemberian terapi antikoagulan secara intensif. ${ }^{10}$ Pemberian aspirin direkomendasikan pada pasien dalam kategori tersebut. Pada kasus ini pasien adalah perempuan usia 77 tahun dengan 3 faktor risiko yaitu adanya gagal jantung, usia $>60$ tahun, dan hipertensi, sehingga pasien ini termasuk dalam kategori risiko tinggi. Berdasarkan petunjuk pemberian terapi antitrombotik maka pasien ini seharusnya diberikan warfarin dengan target INR 2,0 sampai 3,0. Pada pasien ini hanya diberikan aspirin dengan dosis $80 \mathrm{mg}$ per hari mengingat adanya efek samping perdarahan dari terapi warfarin juga mempertimbangkan kepatuhan penderita

Tabel 1. Petunjuk pemberian terapi antitrombotik pada fibrilasi atrium

\begin{tabular}{|c|c|c|}
\hline Karakteristik & $\begin{array}{c}\text { Anjuran Terapi oleh ACC- } \\
\text { AHA dan ESC }\end{array}$ & $\begin{array}{c}\text { Perbedaan tatalaksana dalam } \\
\text { ACCP }\end{array}$ \\
\hline \multicolumn{3}{|l|}{ Umur } \\
\hline $\begin{array}{l}<60 \text { thn, tanpa kelainan } \\
\text { jantung }\end{array}$ & $\begin{array}{l}\text { Aspirin dosis } 325 \mathrm{mg} \text { per hari } \\
\text { atau tidak diterapi }\end{array}$ & $\begin{array}{l}\text { Aspirin dosis } 325 \mathrm{mg} \text { pada pasien } \\
<65 \text { thn tanpa faktor resiko. }\end{array}$ \\
\hline $\begin{array}{l}<60 \text { thn, dengan kelainan } \\
\text { jantung, tanpa faktor } \\
\text { resiko. }\end{array}$ & Aspirin dosis $325 \mathrm{mg}$ per hari & - \\
\hline $\begin{array}{l}\geq 60-75 \text { thn, tanpa faktor } \\
\text { resiko }\end{array}$ & Aspirin dosis $325 \mathrm{mg}$ per hari & $\begin{array}{l}\text { Pilih aspirin dosis } 325 \mathrm{mg} \text { per hari } \\
\text { atau warfarin (INR, 2,0-3,0) untuk } \\
\text { pasien } 65-75 \text { thn. }\end{array}$ \\
\hline $\begin{array}{l}\geq 60 \text { thn, dengan DM atau } \\
\text { PJK }\end{array}$ & $\begin{array}{l}\text { Warfarin (INR 2,0-3,0), } \\
\text { dengan/tanpa aspirin dosis } 81 \text { - } \\
162 \mathrm{mg} \text { per hari }\end{array}$ & $\begin{array}{l}\text { Pilih aspirin dosis } 325 \mathrm{mg} \text { per hari } \\
\text { atau warfarin (INR } 2,0-3,0 \text { ) untuk } \\
\text { pasien dengan hanya DM atau PJK } \\
\text { saja yang berumur }<65 \text { thn }\end{array}$ \\
\hline$>75$ thn, khususnya wanita & $\begin{array}{l}\text { Warfarin (INR, sekitar 2,0; target, } \\
1.6-2.5)\end{array}$ & $\begin{array}{l}\text { Warfarin (INR, 2,0-3,0), tidak } \\
\text { dianjurkan nilai INR }<2,0\end{array}$ \\
\hline $\begin{array}{l}\text { Gagal jantung, fraksi ejeksi } \\
\text { ventrikel kiri } \leq 0.35 \text {, } \\
\text { tirotoksikosis dan hipertensi }\end{array}$ & Warfarin $(\mathrm{INR}, 2,0-3,0)$ & - \\
\hline PJR (stenosis mitralis) & $\begin{array}{l}\text { Warfarin (INR, 2.5-3.5 atau } \\
\text { lebih) }\end{array}$ & $\begin{array}{l}\text { Selain pasien dengan kelainan katup, } \\
\text { tidak dianjurkan INR diatas } 2.5 \\
\text { (rentang } 2,0-3,0)\end{array}$ \\
\hline Riwayat tromboembolisme & $\begin{array}{l}\text { Warfarin (INR, 2.5-3.5 atau } \\
\text { lebih) }\end{array}$ & $\begin{array}{l}\text { Selain pasien dengan kelainan katup, } \\
\text { tidak dianjurkan INR diatas } 2.5 \\
\text { (rentang } 2,0-3,0)\end{array}$ \\
\hline $\begin{array}{l}\text { Trombus atrium persisten pada } \\
\text { ekokardiografi transesofagus }\end{array}$ & $\begin{array}{l}\text { Warfarin (INR, 2.5-3.5 atau } \\
\text { lebih) }\end{array}$ & $\begin{array}{l}\text { Selain pasien dengan kelainan katup, } \\
\text { tidak dianjurkan INR diatas } 2.5 \\
\text { (rentang } 2,0-3,0)\end{array}$ \\
\hline Katup jantung buatan & $\begin{array}{l}\text { Warfarin (INR, 2.5-3.5 atau } \\
\text { lebih) }\end{array}$ & $\begin{array}{l}\text { Tergantung tipe katup buatan, } \\
\text { warfarin (INR, } 2.5 \text { [rentang 2,0-3,0] } \\
\text { atau INR } 3,0 \text { [rentang 2.5-3.5]) } \\
\text { dengan/tanpa tambahan aspirin dosis } \\
80-100 \mathrm{mg}\end{array}$ \\
\hline $\begin{array}{l}\text { Anjuran penggunaan warfarin } \\
\text { tetapi ter-kontraindikasi atau } \\
\text { menolak }\end{array}$ & Aspirin dosis $325 \mathrm{mg}$ per hari & - \\
\hline
\end{tabular}

Dikutip dari American College of Cardiology/American Heart Association/European Society of Cardiology Recommendation for Stroke Prevention in Atrial Fibrillation ${ }^{3}$ 
dalam berobat terutama dalam mengontrol nilai INR serta biaya untuk pengobatan jangka panjang.

Selain dari pemberian antikoagulan, maka terapi farmakologis lainnya ditujukan pada rate control dan/atau rhythm control. Frekuensi ventikuler yang direkomendasikan pada penggunaan terapi berdasarkan rate control adalah berkisar 60 sampai 80 kali per menit. Pemberian digoxin sebagai terapi lini pertama untuk rate control telah diganti dengan pemberian $\beta$-adrenergic blokers, dan calcium-channel blockers. $\mathrm{Pa}-$ da pasien ini diberikan bisoprolol 5mg per hari. ${ }^{8,9}$

Sebagian besar obat-obatan antiaritmia memiliki risiko terjadinya efek samping serius sehingga dalam menentukan pilihan haruslah dipertimbangkan berdasarkan keadaan dan fungsi dari jantung. Untuk pasien dengan gejala yang berat maka pilihan terapi adalah berdasarkan rhythm control dengan mempertimbangkan adanya kontraindikasi seperti perpanjangan interval QT pada EKG, penebalan dinding ventrikel kiri $\geq 1,4$ cm juga pada lansia. ${ }^{11,12}$ Komplikasi yang dapat timbul seperti torsades de pointes, lupus-like syndrome, hipotiroidisme, hepatotoksik, glaukoma dan retensi urin. ${ }^{12}$ Pada kasus ini pasien adalah lanjut usia dengan gejala klinik sesak napas.

Pada pasien lansia pilihan obat-obatan antiaritmia dan antikoagulan dapat berbahaya, sehingga tujuan pengobatan adalah perbaikan gejala klinik. ${ }^{12}$ Pilihan terapi melalui rate control lebih menjadi pilihan sebab efek samping yang lebih minimal serta efikasi yang tidak lebih inferior serta lebih murah dibandingkan rhythm control dalam mempertahankan irama sinus yang juga berpotensi sebagai proaritmia. ${ }^{13}$ Meskipun tercapainya irama sinus normal merupakan

Tabel 2. Pilihan obat-obatan antiaritmia berdasarkan kelainan pada jantung

\begin{tabular}{|c|c|c|c|c|}
\hline \multirow[t]{2}{*}{ Kelainan } & \multirow[t]{2}{*}{ Kontrol denyut } & \multicolumn{3}{|c|}{ Kontrol ritme } \\
\hline & & Pilihan I & Pilihan II & Pilihan III \\
\hline $\begin{array}{l}\text { Minimal atau tidak } \\
\text { ada kelainan }\end{array}$ & $\begin{array}{l}\text { Penyekat beta atau } \\
\text { penyekat kanal kalsi- } \\
\text { um }\end{array}$ & $\begin{array}{l}\text { Flecainide, } \\
\text { propafenone, } \\
\text { sotalol }\end{array}$ & $\begin{array}{l}\text { Amiodarone, } \\
\text { dofetilide }\end{array}$ & $\begin{array}{l}\text { Disopyramide, } \\
\text { procainamide, } \\
\text { quinidine (atau opsi } \\
\text { nonfarmakologis) }\end{array}$ \\
\hline $\begin{array}{lr}\text { Fibrilasi atrium } \\
\text { adregenik dengan } \\
\text { kelainan jantung } \\
\text { minimal atau tidak }\end{array}$ & Penyekat beta & $\begin{array}{l}\text { Penyekat } \\
\text { beta atau } \\
\text { sotalol }\end{array}$ & $\begin{array}{l}\text { Amiodarone, } \\
\text { dofetilide }\end{array}$ & - \\
\hline Gagal jantung & $\begin{array}{l}\text { Penyekat beta, bila } \\
\text { ditoleransi; digoksin }\end{array}$ & $\begin{array}{l}\text { Amiodarone } \\
\text { dofetilide }\end{array}$ & - & - \\
\hline $\begin{array}{l}\text { Penyakit jantung } \\
\text { koroner }\end{array}$ & Penyekat beta & Sotalol & $\begin{array}{l}\text { Amiodarone, } \\
\text { dofetilide }\end{array}$ & $\begin{array}{l}\text { Disopyramide, } \\
\text { procainamide, } \\
\text { quinidine }\end{array}$ \\
\hline $\begin{array}{l}\text { Hipertensi dengan } \\
\text { LVH tetapi tebal } \\
\text { dinding }<1,4 \mathrm{~cm}\end{array}$ & $\begin{array}{l}\text { Penyekat beta atau } \\
\text { penyekat kanal kalsi- } \\
\text { um }\end{array}$ & $\begin{array}{l}\text { Flecainide, } \\
\text { propafenone }\end{array}$ & $\begin{array}{l}\text { Amiodarone, } \\
\text { dofetilide, } \\
\text { sotalol }\end{array}$ & $\begin{array}{l}\text { Disopyramide, } \\
\text { procainamide, } \\
\text { quinidine }\end{array}$ \\
\hline $\begin{array}{l}\text { Hipertensi dengan } \\
\mathrm{LVH} \text { dan tebal } \\
\text { dinding } \geq 1,4 \mathrm{~cm}\end{array}$ & $\begin{array}{l}\text { Penyekat beta atau } \\
\text { penyekat kanal kalsi- } \\
\text { um }\end{array}$ & Amiodarone & - & - \\
\hline
\end{tabular}

Dikutip dari American College of Cardiology/American Heart Association/European Society of Cardiology Recommendation for Stroke Prevention in Atrial Fibrillation. ${ }^{3}$ 
tujuan dari terapi pada pasien dengan gagal jantung kongestif dan fibrilasi atrium, pemakaian terapi berdasarkan rhythm control masih sukar dicapai sepenuhnya dalam mempertahankan keadaan irama sinus normal serta efek samping yang minimal. ${ }^{14}$ Pilihan terapi berdasarkan rate control dapat dipertimbangkan sebagai terapi primer pada pasien dengan fibrilasi atrium dan gagal jantung kongestif. Pemakaian $A C E$ inhibitor dan $\beta$-adrenergic bloker adalah penting terutama dalam mencegah onset terjadinya AF. ${ }^{15}$ Pada pasien ini diberikan captopril $6.25 \mathrm{mg}$ tiga kali sehari serta bisoprolol $5 \mathrm{mg}$ satu kali sehari.

Prognosis pada pasien dengan fibrilasi atrium tergantung dari faktor-faktor risiko yang dimiliki pasien. ${ }^{16}$ Dalam kasus ini pasien adalah perempuan usia 77 tahun dengan gagal jantung kongestif fungsional I-II karena penyakit jantung hipertensi, sehingga pasien ini termasuk dalam kategori risiko tinggi.

Tabel 3. Faktor-faktor risiko pada fibrilasi atrium

\begin{tabular}{ll}
\hline \multicolumn{1}{c}{ High Risk } & \multicolumn{1}{c}{ Moderate Risk } \\
\hline Prior stroke, TIA & Age 65-75 years \\
Systemic embolism & Diabetes \\
Hypertension & Coronary artery disease \\
Poor LV function & \\
Age $>75$ years & \\
Rheumatic mitral disease & \\
Prosthetic heart valves & \\
\hline
\end{tabular}

Dikutip dari American College of Cardiology/ American Heart Association/European Society of Cardiology Recommendation for Stroke Prevention in Atrial Fibrillation. ${ }^{3}$

\section{KESIMPULAN}

Telah dilaporkan sebuah kasus fibrilasi atrium dengan gagal jantung kongestif fungsional I-II karena penyakit jantung hipertensi. Diagnosis ditegakkan berdasarkan anamnesis, gambaran klinik, pemeriksaan EKG dan X-foto dada. Pasien diberi terapi bisoprolol $5 \mathrm{mg}$ sekali per hari, ceftriaxon 1g dua kali sehari, captopril 6,25 mg tiga kali sehari, tiazid $25 \mathrm{mg}$ sekali sehari, furosemid $40 \mathrm{mg}$ sekali sehari, coenzim
Q10 $100 \mathrm{mg}$ dua kali sehari, trimetazidine $35 \mathrm{mg}$ dua tablet sehari, dan aspirin $80 \mathrm{mg}$ sekali per hari. Selama perawatan terjadi perbaikan yang berarti terutama berkurangnya sesak napas, juga terjadi perbaikan pada gambaran EKG yaitu perubahan dari fibrilasi atrium rapid response menjadi normal respone beberapa jam setelah pemberian $\beta$ adrenergic blocker (tablet bisoprolol $5 \mathrm{mg}$ ).

\section{DAFTAR PUSTAKA}

1. Olgin JE, Zipes DP. Atrial fibrillation. In: Libby P, Bonow RO, Mann DL, Zipes DP (eds). Braunwald's heart disease $8^{\text {th }}$ ed. Philadelphia: Saunders Elsevier, 2008; p.869-72.

2. Prystowsky EN, Katz A. Atrial fibrillation. In: Topol EJ, Robert MC, Isner J, et al (eds). Textbook of cardiovascular medicine $2^{\text {nd }}$ ed. Baltimore: Lippincott Williams and Wilkins, 2002; p.1342-88.

3. Page RL, Newly diagnosed atrial fibrillation. N Engl J Med. 2004;351:2408-16.

4. Wang TJ, Benjamin EJ. The Epidemiology of Atrial Fibrillation. In: Kowey P, Naccarelli GV (ed) Atrial Fibrillation. New York: Marcel Dekker, 2005; p.1-27.

5. Maisel WH, Stevenson LW. Atrial fibrillation in heart failure: epidemiology, pathophysiology, and rationale for therapy. Am J Cardiol. 2003;91(suppl):2D-8D.

6. Podrid PJ. Etiology and Pathogenesis of Atrial Fibrillation. In: Kowey P, Naccarelli GV (ed) Atrial Fibrillation. New York: Marcel Dekker, 2005; p.27-61.

7. Falk RH. Atrial fibrillation. N Engl J Med 2001;344:1067-78.

8. Wyse DG. Rate Control Versus Maintenance of Sinus Rhythm. In: Kowey P, Naccarelli GV (ed) Atrial Fibrillation. New York: Marcel Dekker, 2005; p.10921.

9. Roy D, Talajic M, Nattel S. Rhythm control versus rate control for atrial fibrillation and heart failure. N Engl J Med. 2008;358:2667-77.

10. Flaker GC, Murtaza M. Atrial Fibrillation and Anticoagulation. In: Kowey P, Naccarelli GV (ed) Atrial Fibrillation. New York: Marcel Dekker, 2005; p.135-59.

11. Kareti KR, Chiong JR, Hsu SS, Miller AB. Congestive Heart Failure and Atrial 
Fibrillation: Rhythm Versus Rate Control. Journal of Cardiac Failure. 2005;11(3):164-173.

12. Camm J. Safety considerations in the pharmacological management of atrial fibrillation. International Journal of Cardiology. 2008;127:299-306.

13. Olshansky B, Rosenfeld LE, Warner AL. The Atrial Fibrillation Follow-Up Investigation of Rhythm Management (AFFIRM) Study. Approaches to Control Rate in Atrial Fibrillation. J Am Coll Cardiol. 2004;43:1201-8.

14. Fauchier L, Grimand C, Pierre B. Comparison of beta blocker and digoxin alone and in combination for manage- ment of patient with atrial fibrillation and heart failure. Am J Cardiol. 2009;103:248-254.

15. Meng F, Yoshikawa T, Baba A. $\beta$-Blockers Are Effective in Congestive Heart Failure Patients With Atrial Fibrillation. Journal of Cardiac Failure. 2003;9(5): 398-403.

16. Fung JW, Skiva KW, Leata YC, Sanderson JE. Is beta-blockade useful in heart failure patients with atrial fibrillation? An analysis of data from two previously completed prospective trials. The European Journal of Heart Failure. 2002;4:489-494. 